\title{
Modeling of Electrical Characteristics of Photovoltaic Cell Considering Single-Diode Model
}

\author{
M. Azzouzi, D. Popescu, and M. Bouchahdane
}

\begin{abstract}
Solar energy is one of the most important types of renewable energies. Many models of solar cell had been proposed since the beginning of the solar energy exploitation. The present paper focuses on single-diode photovoltaic cell models. The I-V and P-V characteristics are presented for each model in function of the series resistance, the shunt resistance, the temperature and the irradiation. More than that, a comparison between an ideal model single-diode solar cell, a model of single-diode solar cell with a series resistance and a model of single-diode solar cell with series and shunt resistances is also presented. Different results were visualized and commented and a conclusion had been drawn.
\end{abstract}

Index Terms - PV cell, solar energy, single diode, modeling, I-V/P-V characteristics, 1M3P, 1M4P, 1M5P.

\section{INTRODUCTION}

In recent years, significant photovoltaic deployment has occurred, particularly in many developed countries. Also, PV energy is going to become an important source in coming years it has highest source of sunshine radiation. This last is composed of photons of different energies, and some are absorbed at the PN junction. Photons with energies lower than the band gap of the solar cell are useless and generate no voltage or electric current. Photons with energy superior to the band gap generate electricity, but only the energy corresponding to the band gap is used [1].

Solar cells are basically made of semiconductors which are manufactured using different process. These semiconductors convert the energy of sunlight directly into electricity by the photovoltaic effect. Many mathematical models have been developed to represent the highly nonlinear behavior resulting from semiconductor junctions in order to assess the performance of the PV cell. In our case, we consider single diode model [2].

\section{Modeling OF Single Diode Solar Cell}

Equivalent circuit models define the entire I-V curve of a cell, module, or array as a continuous function for a given set of operating conditions. Three equivalent circuit models can be used to describe a single diode model such as: the ideal solar cell or the 1M4P model, solar cell with series resistance called also 1M5P, and solar cell with series and shunt

Manuscript received March 17, 2015; revised September 16, 2015

M. Azzouzi and M. Bouchahdane are with Ziane Achour University of Djelfa, Cite Ain Chih BP 317, Algeria (e-mail: Dr.Azzouzi@yahoo.fr).

D. Popesscu is with the Department of Automatic Control and Systems Engineering, Faculty of Automatic Control and Computers, University Politenica of Bucharest, Splaiul Independentei 313, 060042, Bucharest, Romania (e-mail: dpopescu@indinf.pub.ro). resistances which is called $1 \mathrm{M} 5 \mathrm{P}$.

\section{A. Ideal Solar Cell (1M4P)}

The I-V characteristics of a solar cell have an exponential characteristic similar to that of a diode [3]. The ideal equivalent circuit of solar cell is a current source in parallel with a single-diode. This model involves the following four unknown parameters: $m, I_{p h}$, and $I_{s}$, this model is also called 1M3P (Single Mechanism, Three Parameters). The configuration of the simulated ideal solar cell with single-diode is shown in Fig. 1.

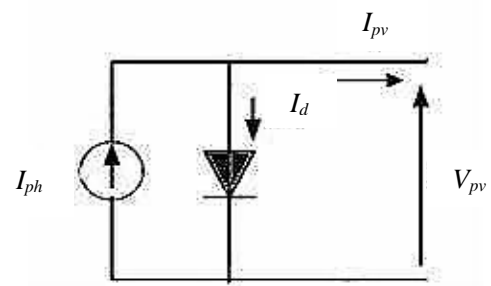

Fig. 1. Equivalent model of single diode ideal solar cell (1M3P).

The characteristic equation is deduced directly from the Kirchhoff law:

$$
I_{p v}=I_{p h}-I_{d}
$$

The diode current is $I_{d}=I_{s}\left(e^{\frac{q V_{p v}}{m k T}}-1\right)$ so the output current is presented by the following non linear I-V equation:

$$
I_{p v}=I_{p h}-I_{s}\left(e^{\frac{q V p v}{m k T}}-1\right)
$$

For the same irradiation and PN junction temperature conditions, the short circuit current $I_{s c}$ is the greatest value of the current generated by the cell and the open circuit voltage $V_{o c}$ is the greatest value of the voltage at the cell terminals [3]. They are given by:

$$
I_{s c}=I_{p v}=I_{p h}
$$

for $V_{p v}=0$

$$
V_{p v}=V_{o c}=\frac{m k T}{q} \ln \left(1+\frac{I_{s c}}{I_{s}}\right)
$$

for $I_{p v}=0$

The output power is

$$
P=V_{p v}\left[I_{s c}-I_{s}\left(e^{\frac{q V p v}{m k T}}-1\right)\right]
$$




\section{B. Solar Cell with Series Resistance}

More accuracy can be introduced to the model by adding a series resistance. The electric scheme equivalent to this model is shown in Fig. 2. This model involves the following four unknown parameters: $m, I_{p h}, R_{s}$ and $I_{s}$ model which is also called 1M4P (Single Mechanism, Four Parameters) [4].

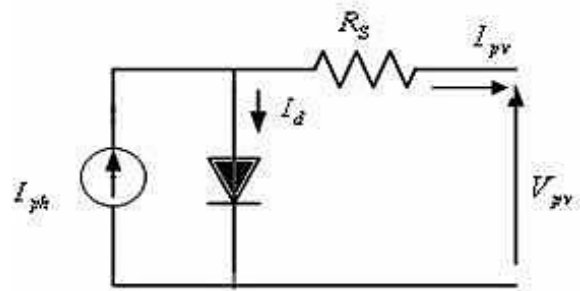

Fig. 2. Equivalent model of single diode solar cell with series resistance (1M4P).

The diode current is:

$$
I_{d}=I_{s}\left(e^{\frac{q\left(V_{p v}+R_{s} I_{p v}\right)}{m k T}}-1\right)
$$

Therefore, the I-V characteristics of the solar cell with single-diode and series resistance are given by:

$$
I_{p v}=I_{p h}-I_{s}\left(e^{\frac{q\left(V_{p v}+R_{S} I_{p v}\right)}{m k T}}-1\right)
$$

For the same irradiation and PN junction temperature conditions, the inclusion of a series resistance in the model implies the use of a recurrent equation to determine the output current in function of the terminal voltage. A simple iterative technique initially tried only converged for positive currents [5].

\section{Solar Cell with Series and Shunt Resistances (1M5P)}

The photovoltaic cell in this case is represented by the circuit of Fig. 3 which consists of a current source modeling the light flux, the losses are modeled by two resistances: shunt resistance, and series resistance. The model thus involves the following five unknown parameters: $m, I_{p h}, R_{s}$, $R_{s h}$ and $I_{s}$. This model is also called 1M5P (Single Mechanism, Five parameters) [4].

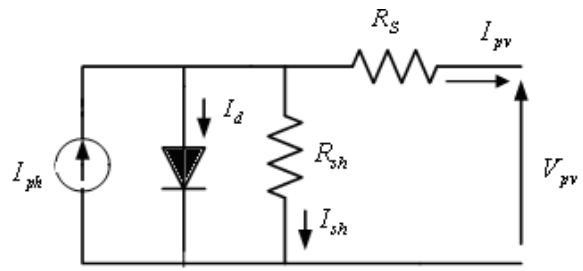

Fig. 3. Equivalent model of single diode solar cell with series and shunt resistances (1M5P).

The characteristic equation can be deduced directly by using the Kirchhoff law:

$$
I_{p v}=I_{p h}-I_{d}-I_{s h}
$$

where the diode current is:

$$
I_{d}=I_{S}\left(e^{\frac{q\left(V_{p v}+R_{S} I_{p v}\right)}{m k T}}-1\right)
$$

And the shunt current is: $I_{S h}=\frac{V+R_{S} I_{p v}}{R_{S h}}$

The relationship between the PV cell output current and terminal voltage according to the single-diode model is governed by equation:

$$
I_{p v}=I_{p h}-I_{s}\left(e^{\frac{q\left(V_{p v}+R_{S} I p v\right)}{m k T}}-1\right)-\frac{V_{p v}+R_{S} I_{p v}}{R_{S h}}
$$

For the same irradiation and PN junction temperature conditions, the inclusion of a series resistance in the model implies the use of a recurrent equation to determine the output current in function of the terminal voltage. A simple iterative technique initially tried only converged for positive currents [6].

The modeling of the PV cell in the three cases was done applying the previous equations. Many types of simulation are carried out depending on the chosen model and the selected parameters.

\section{INFLUENCES OF ENVIRONMENTAL AND PHYSICAL PARAMETERS}

\section{A. Influence of Irradiation and Temperature}

In the three models, the temperature is maintained constant at $25^{\circ} \mathrm{C}$ and by varying the irradiation $\left(250 \mathrm{~W} / \mathrm{m}^{2}, 500 \mathrm{~W} / \mathrm{m}^{2}\right.$, $750 \mathrm{~W} / \mathrm{m}^{2}, 1000 \mathrm{~W} / \mathrm{m}^{2}$ ). Fig. 4 shows the Matlab program results under these conditions on $\mathrm{I}-\mathrm{V}$ and $\mathrm{P}-\mathrm{V}$ characteristics respectively. It is clear that current generated by the incident light depends on irradiation, the higher the irradiation, the greater the current. On the other hand, voltage is staying almost constant and it is not going to. The influence of irradiation on maximum power point is clear, the higher the irradiation, the major of the maximum power point will be [6].

Second, the irradiation is maintained constant at $1000 \mathrm{~W} / \mathrm{m}^{2}$ and varying temperature $\left(25^{\circ} \mathrm{C}, 50^{\circ} \mathrm{C}, 75^{\circ} \mathrm{C}\right.$, $100^{\circ} \mathrm{C}$ ) will generate the characteristic curves.

Fig. 5 show the simulation results of $\mathrm{I}-\mathrm{V}$ and $\mathrm{P}-\mathrm{V}$ characteristics respectively under the same conditions. The current generated by the incident light is going to stay constant although it increases slightly while the voltage decreases.

The effect of the temperature increase decreases voltage and power. Fig. 6 shows the influence of both the irradiation and the temperature, we can remark that the I-V and P-V curves are similar to these of the irradiation influence with slightly higher values of power; the effect of the temperature in this case is almost ignored [5].

\section{B. Influence of Series Resistance and Temperature}

Fig. 7 shows the influence of the serial resistance on the characteristic I-V and $\mathrm{P}-\mathrm{V}$ of $1 \mathrm{M} 4 \mathrm{P}$ and 1M5P photovoltaic cells. The series resistance is the slope of the characteristic in the area where the PV cell behaves as a voltage generator it does not change the open circuit voltage, and when it is high, it decreases the value of the short circuit current. The increase of the series resistance results in a decrease in the slope of the power curve. The influence of both the series resistance and the temperature on the same previous models is presented in Fig. 8, where the short circuit current took the same value while the open circuit voltage is increased [5]. 

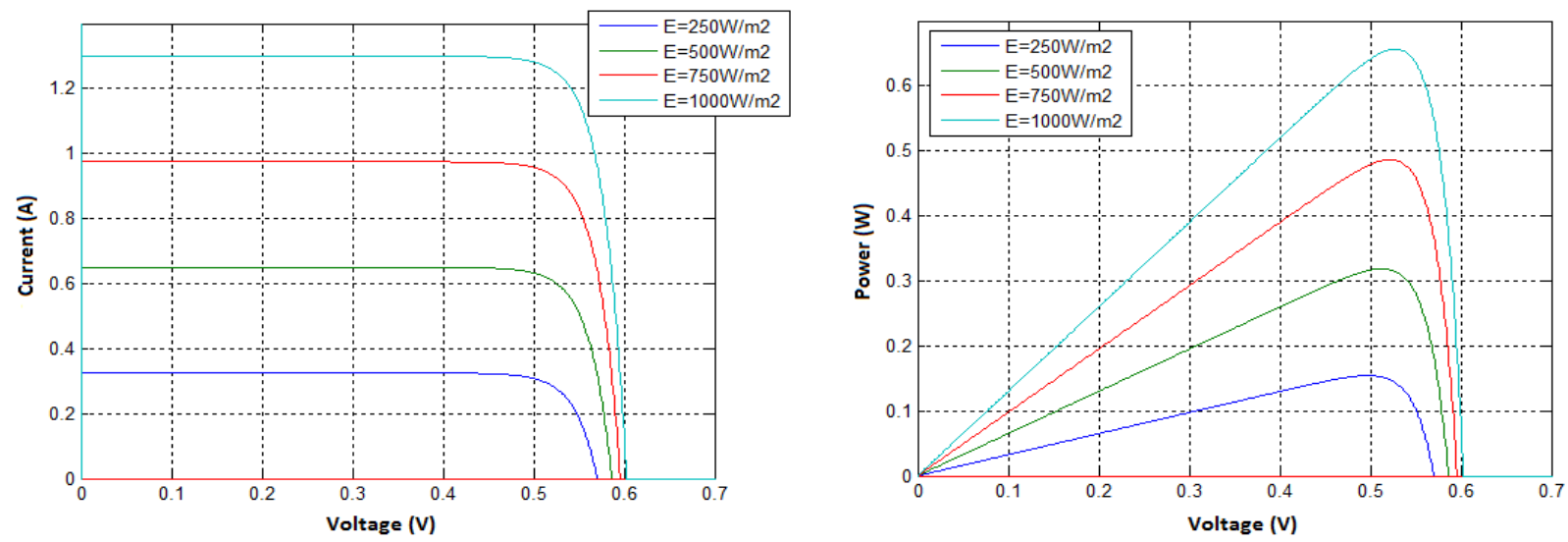

Fig. 4. Influence of the irradiation.
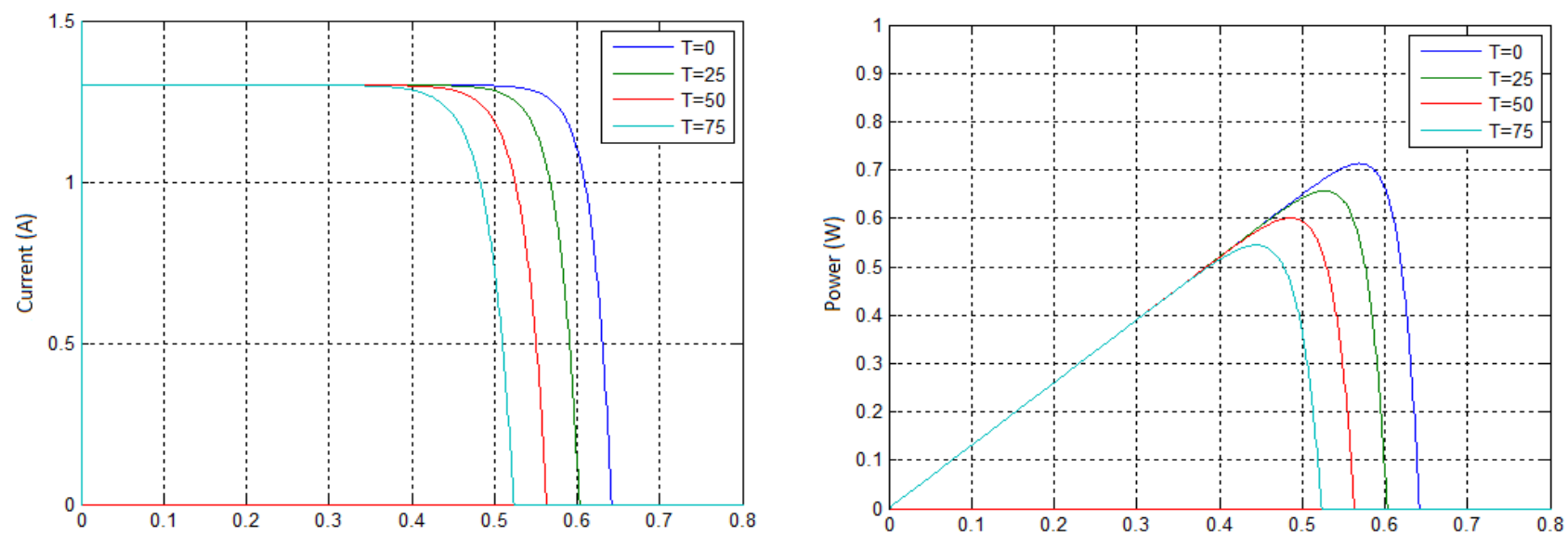

Fig. 5. Influence of the temperature.
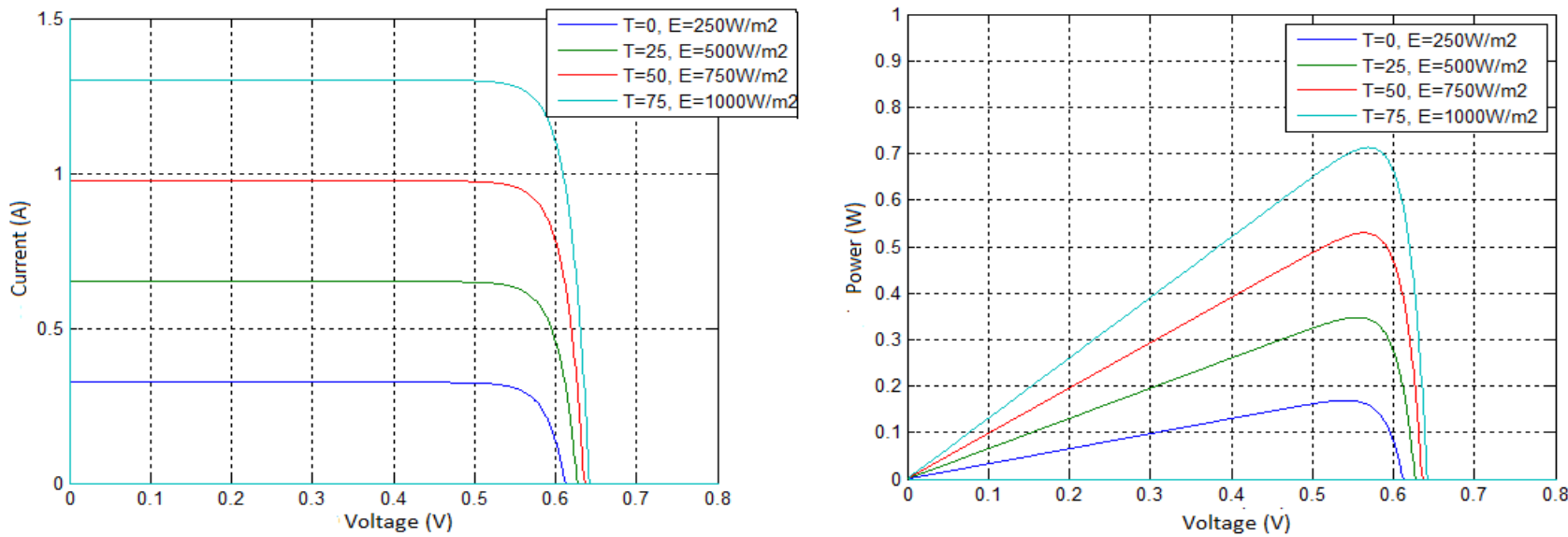

Fig. 6. Influence of temperature and irradiation.
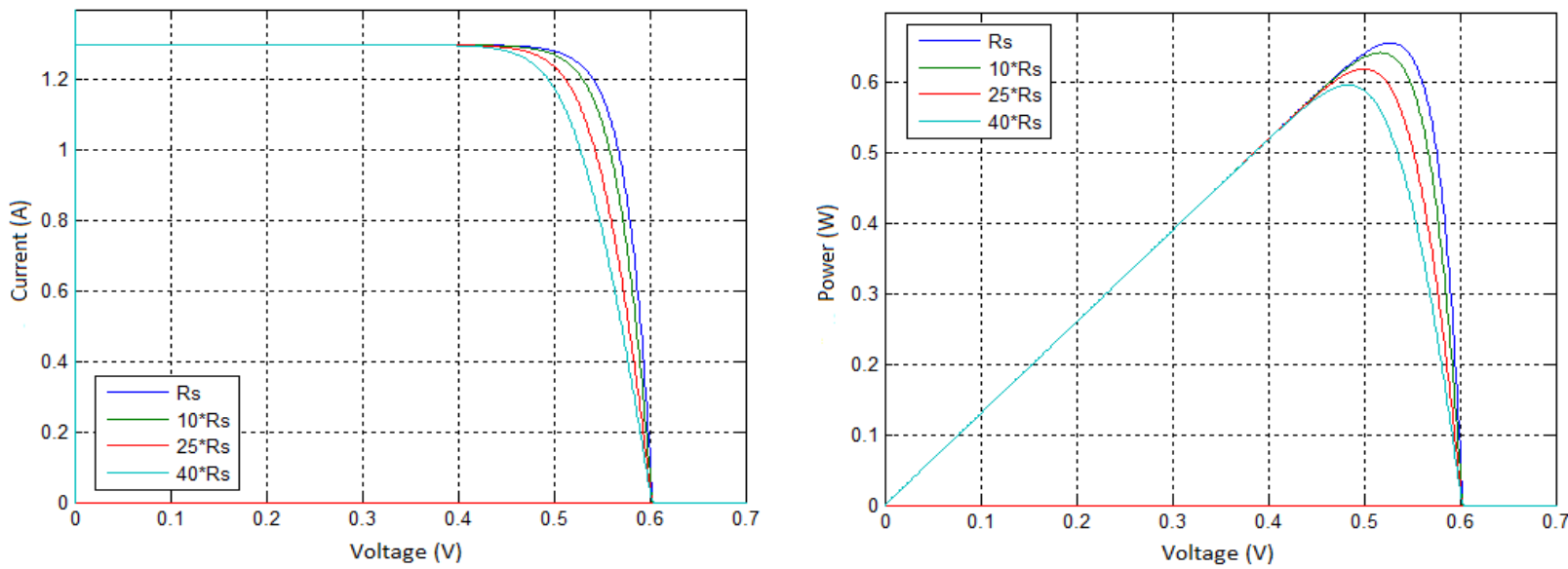

Fig. 7. Influence of series resistance. 

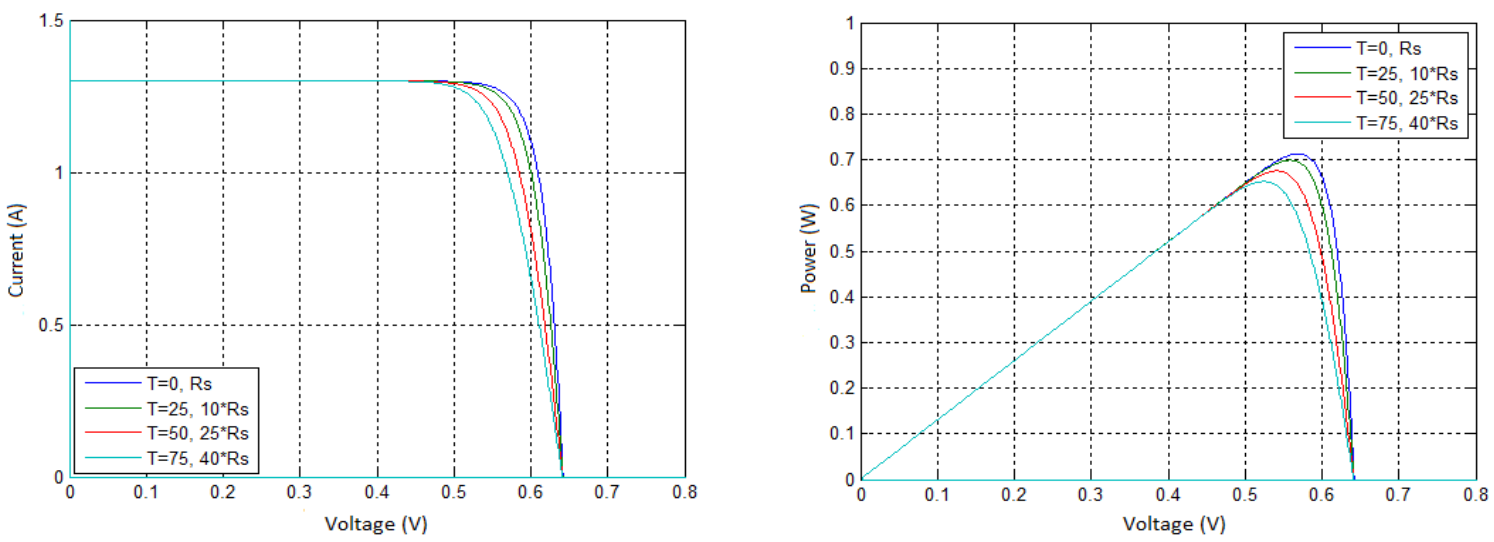

Fig. 8. Influence of series resistance and temperature.
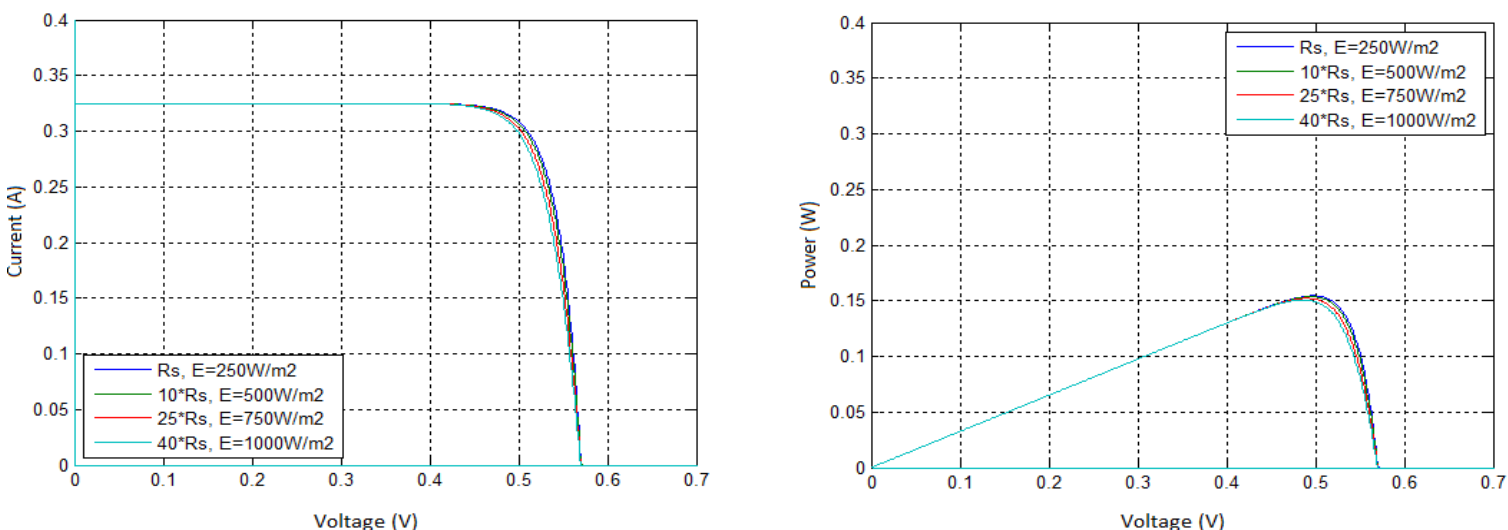

Fig. 9. Influence of series resistance and irradiation for 1M4P model.
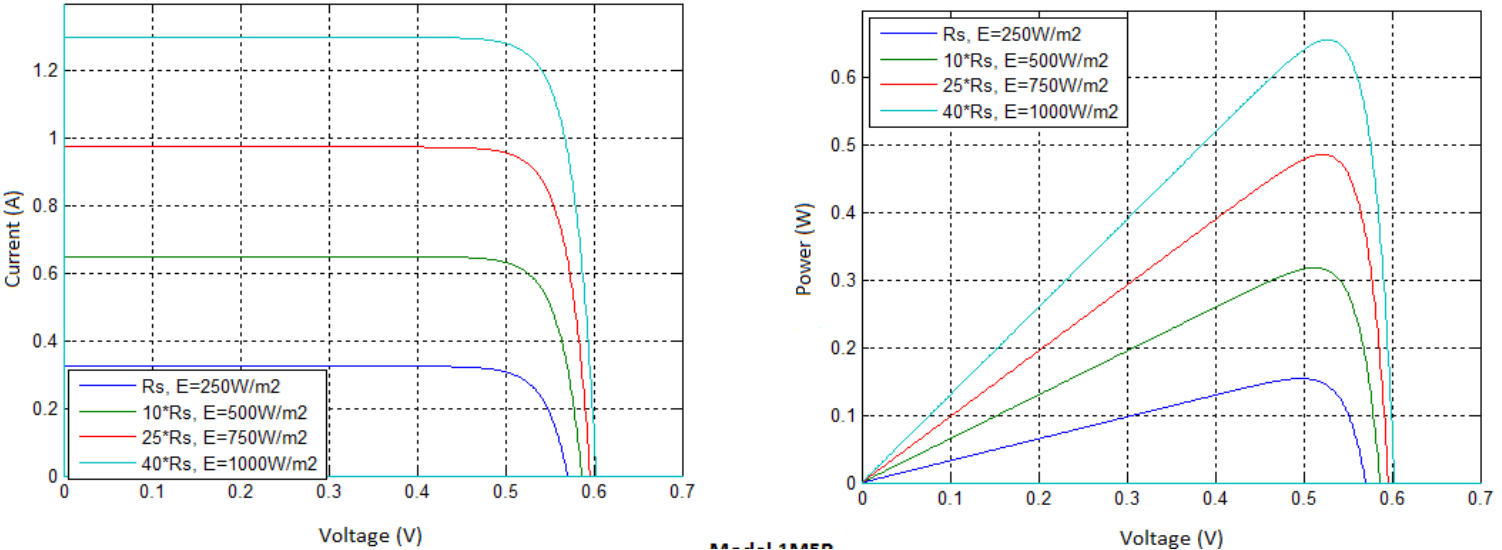

Fig. 10. Influence of series resistance and irradiation for 1M5P model.

\section{Influence of Series Resistance and Irradiation}

The Fig. 9 and Fig. 10 show the importance of the series resistance, which indicates the difference between the different models. In Fig. 10, the performance of a 1M4P PV cell is much degraded when Rs and the irradiation are high, on the other side the model $1 \mathrm{M} 5 \mathrm{P}$ is not so influenced by the series resistance as the 1M4P model [7].

\section{Influence of Shunt Resistance and Temperature}

The shunt resistance is a resistance which takes into account the unavoidable leakage of current that occurs between the terminals of a solar cell. In general, when the shunt resistance is very high, its effect is felt especially in the generation of power. The influence of the shunt resistance on the current-voltage characteristics results in a slight decrease in open circuit voltage and an increase of the slope of the I-V curve of the cell in the area corresponding to operation as a source of current [8] (see Fig. 12)

\section{E. Influence of Shunt and Series Resistances}

Fig. 13 shows the effect of the two resistors series and parallel at the same time, where it can be concluded that the effect of the series resistance is negligible, relative to the shunt resistance. A minimization of the value of the shunt resistance induces an estrangement from the real operation of the cell [9].

\section{$F$. Influence of Shunt Resistance and Irradiation}

Fig. 14 presents the simultaneous influence of shunt resistance and the irradiation on a 1M5P model, from which we can collude that the I-V and P-V characteristics are similar to these of the shunt resistance influence shown in Fig. 11 , with the same values of short circuit current and open circuit voltage, so the shunt resistance influence in this case was been ignored relative to the irradiation influence. 

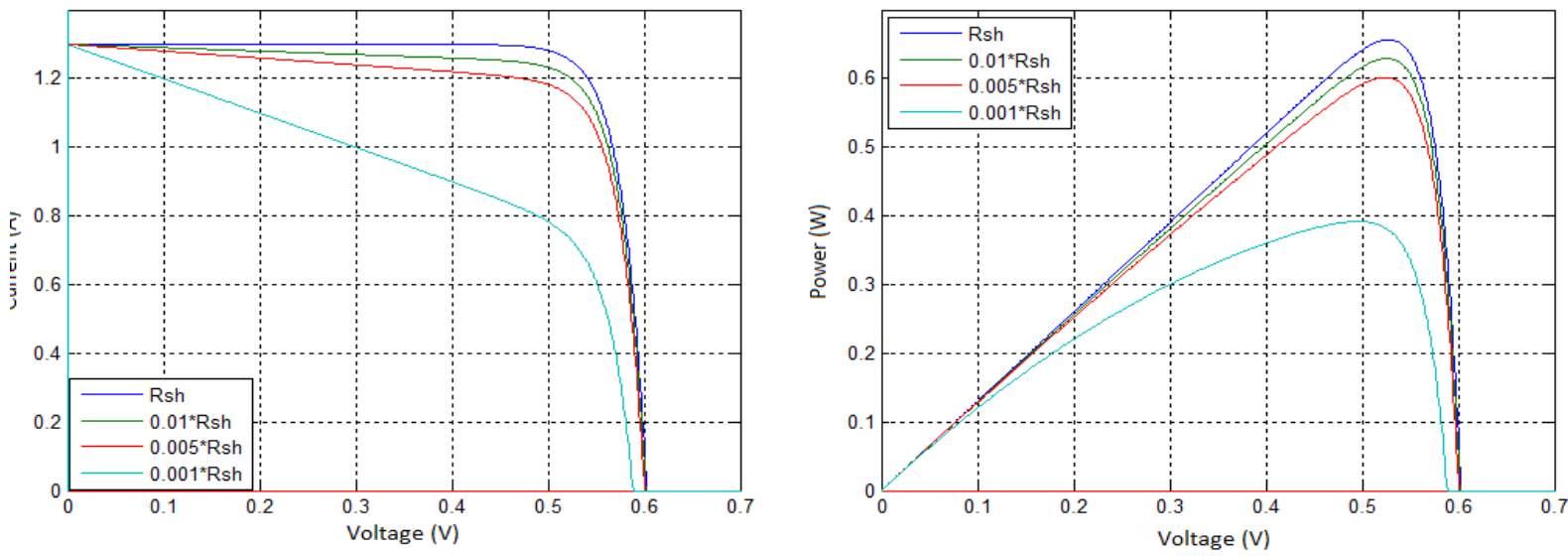

Fig. 11. Influence of shunt resistance.
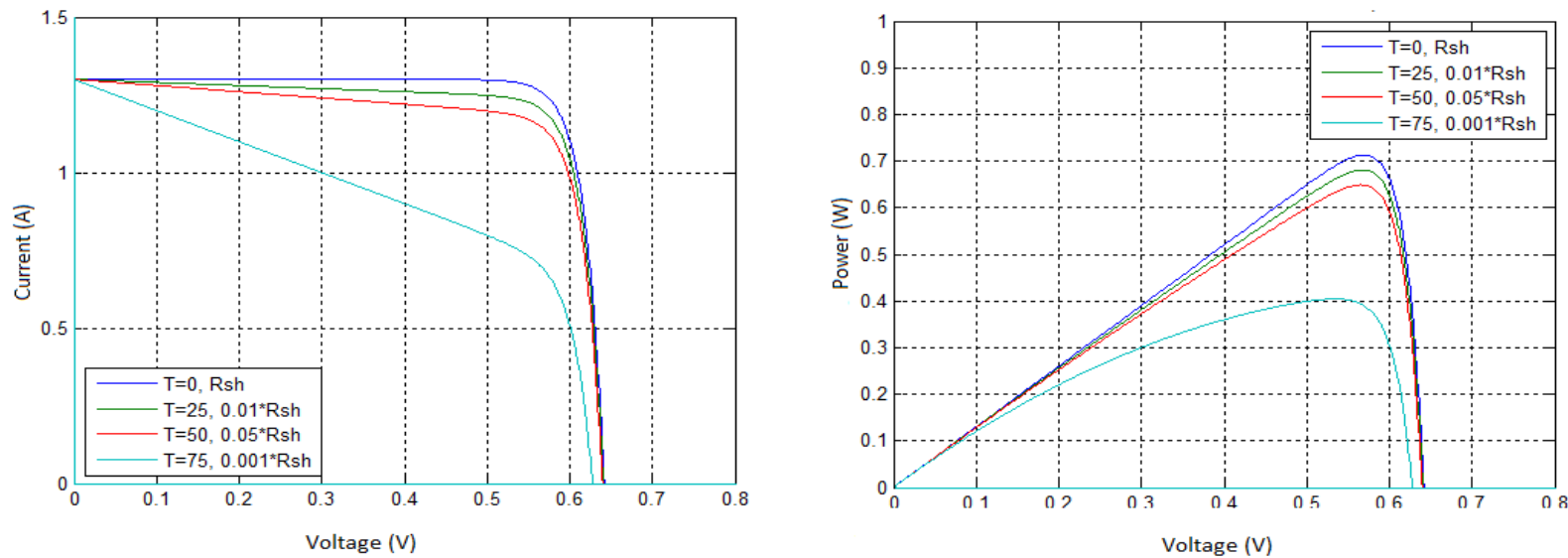

Fig. 12. Influence of shunt resistance and temperature.
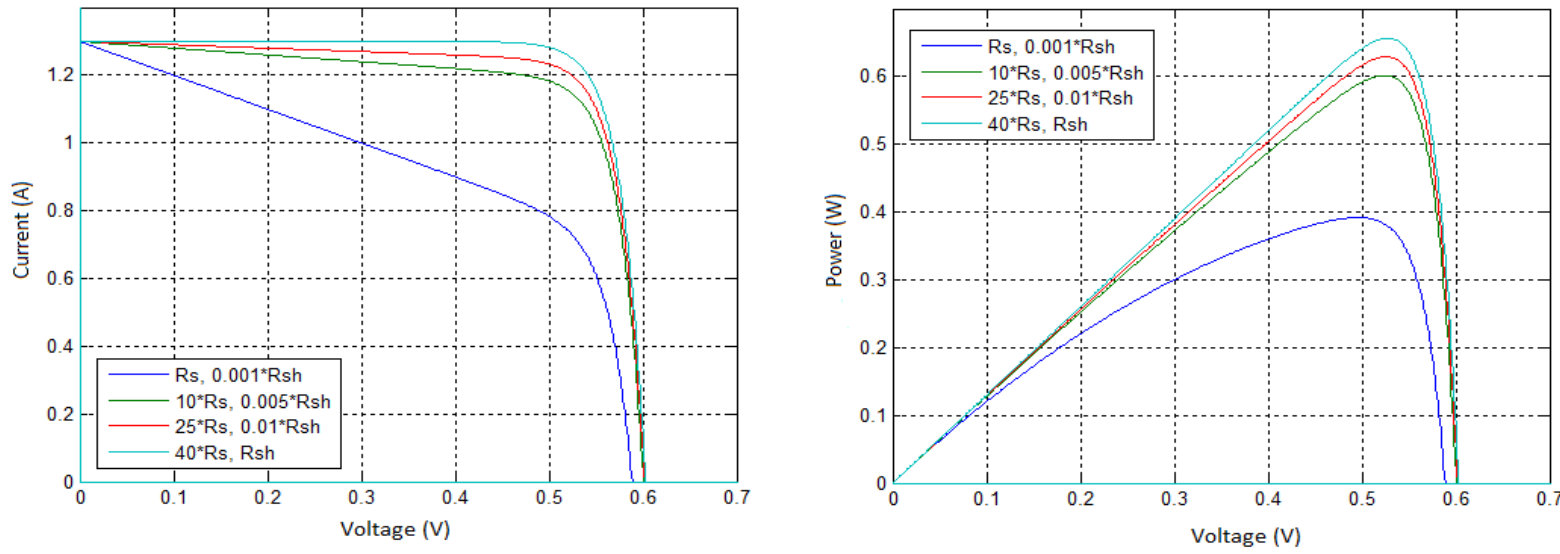

Fig. 13. Influence of shunt and series resistance.
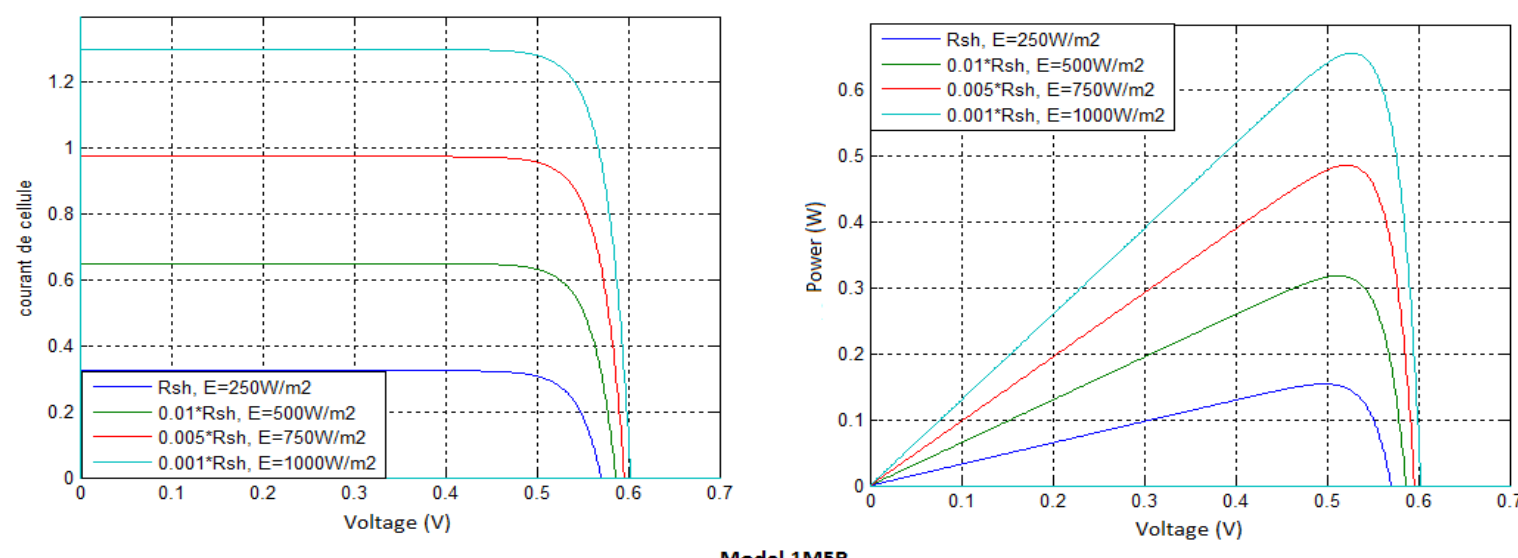

Fig. 14. Influence of shunt resistance and irradiation. 

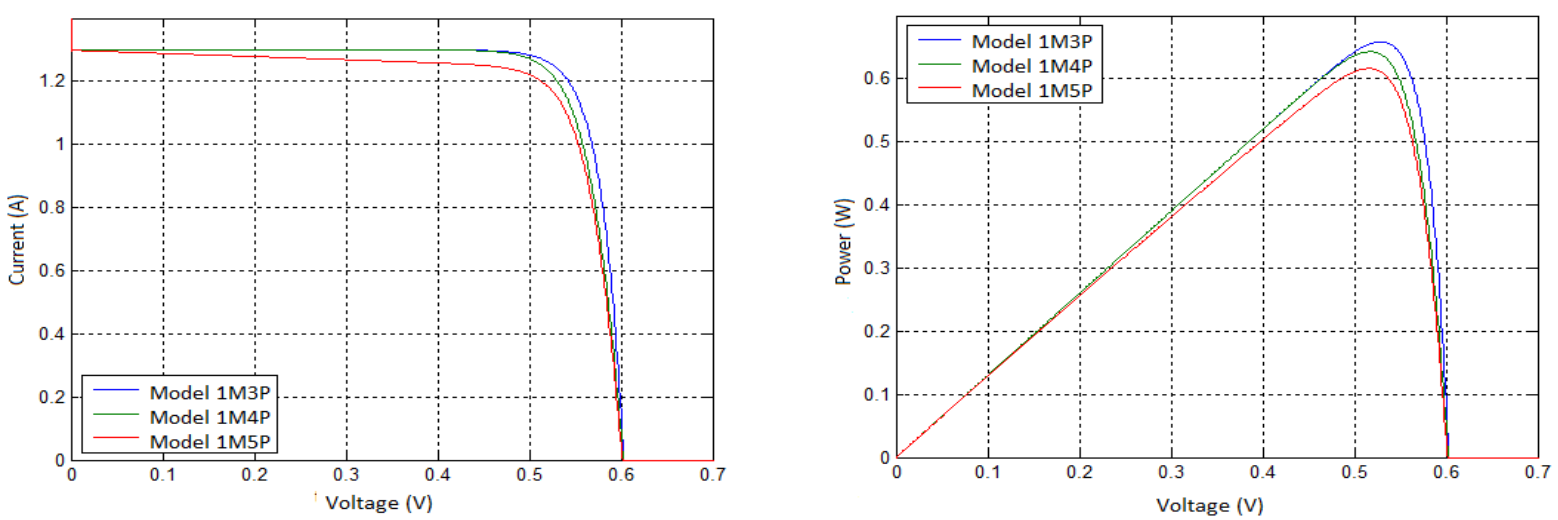

Fig. 15. Comparison between the three models of single diode PV cell.

\section{COMPARISON Between THE THREe Models}

The same reference condition is selected for each model. The performance of the solar cell is normally evaluated in the test normalizes conditions (STC), the irradiation is normalized to $1000 \mathrm{~W} / \mathrm{m}^{2}$, and temperature to $25^{\circ} \mathrm{C}$. Fig. 15 presents a comparison between different models of single diode PV cell from which we can note that $1 \mathrm{M} 3 \mathrm{P}$ has the optimized performances of the single diode model with higher values of current and power, contrariwise the 1M5P gives the lower values of current and power, hence the 1M4P curves proves that it is the most accurate model since it is closer to the real operation of the PV cell [10]-[13].

\section{CONCLUSION}

In this paper, we have presented the fundamental electric characteristics of photovoltaic cell of single diode where all the equivalent circuits were described, and the equivalent models were discussed. A comparison between these models demonstrated that the solar cell with series resistance model (1M4P) offers a more realistic behavior for the photovoltaic systems while it combines between the simplicity and the precision. The single diode model was analyzed in function of physical phenomena such as the resistance series and the resistance shunt, and the environmental parameters as the irradiation and the temperature.

\section{APPENDIX}

\section{PV: Photovoltaic}

I-V: current-voltage

$\mathrm{P}-\mathrm{V}$ : power-voltage

1M3P: single mechanism, three parameters

1M4P: single mechanism, four parameters

1M5P: single mechanism, five parameters

$I_{p h}[\mathrm{~A}]:$ the current generated by the incident light

$I_{s}[\mathrm{~A}]:$ the diode reverse bias saturation current

$I_{s h}[\mathrm{~A}]:$ the shunt resistance current

$I_{s c}[\mathrm{~A}]$ :short circuit current

$I_{p v}[\mathrm{~A}]:$ the output current

$V_{p v}[\mathrm{~V}]$ : the terminal voltage

$V_{p h}[\mathrm{~V}]$ : the photovoltaic voltage

$I_{d}[\mathrm{~A}]:$ the diode current

$V_{o c}[\mathrm{~V}]$ : open circuit voltage

$q$ : the electron charge $\left[1.60217646 \times 10^{-19} \mathrm{C}\right]$

$k$ : the Boltzmann constant $\left[1.3806503 \times 10^{-23} \mathrm{~J} / \mathrm{K}\right]$

$T[\mathrm{~K}]$ : the temperature of the PN junction
$E\left[\mathrm{~W} / \mathrm{m}^{2}\right]$ is the irradiation

$R_{s}[\Omega]$ : series resistance

$R_{\text {sh }}[\Omega]$ : shunt resistance

$m$ : the ideality factor of the diode

\section{REFERENCES}

[1] J. Bikaneria et al., "Modeling and simulation of PV cell using one-diode model," IJSRP, vol. 3, issue 10, 2013.

[2] N. Belhaouas, M. S. A. Cheikh, A. Malek, and C. Larbes, "Matlab-Simulink of photovoltaic system based on a two-diode model simulator with shaded solar cells," Revue des Energies Renouvelables, vol. 16 , no. 1, pp. 65-73, 2013.

[3] E. M. G. Rodrigues et al., "Simulation of a solar cell considering single-diode equivalent circuit model," in Proc. International Conference on Renewable Energies and Power Quality, 2011.

[4] B. Bentouati, "Etude comparative de deux cellules photovoltaïques," Master in Automatic Control, University of Djelfa, 2012.

[5] B. Alsayid, "Modeling and simulation of photovoltaic cell/module/array with two-diode model," IJCTEE, vol. 1, no. 3, 2012.

[6] D. Bonkoungou, Z. Koalaga, and D. Njomo, "Modelling and Simulation of photovoltaic module considering single-diode equivalent circuit model in MATLAB," International Journal of Emerging Technology and Advanced Engineering, vol. 3, issue 3, 2013.

[7] T. Salmi et al., "MATLAB/Simulink based modeling of solar photovoltaic cell," International Journal of Renewable Energy Research, vol. 2, no. 2, 2012.

[8] K. Hellali, "Modelisation d'une cellule photovoltaique: etude comparative," Master in Electrotechnique, Universite Mouloud Mammri de Tizi-Ouzou, 2012.

[9] A. O. M. Yahya et al., "Etude et modélisation d'un générateur photovoltaïque," R. des Energies Renouvelables, vol. 11, pp. 473-483.

[10] Z. Zhao, "1D modeling of solar cells," Columbia University.

[11] Single Diode Equivalent Circuit Models. [Online]. Available: http://pvpmc.org/modeling-steps/module-iv-curve/diode-equivalent-ci rcuitmodels/

[12] Electrical engineering. [Online]. Available: http://www.ee.columbia.edu/ lavaei/Projects/ZZ.pdf

[13] CSI, Inc. [Online]. http://www.californiascientific.com/resource/Solar\%20Cell.pdf

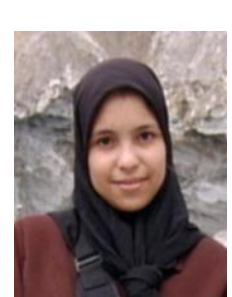

Messaouda Azzouzi was born in Djelfa, Algeria in 1980, she got her baccalaureate degree in natural and life sciences form Belahrach Said Hight Schoul in Djelfa in 1997, engineering diploma in electronics from Ziane Achour University of Djelfa, Algeria in 2002. As a major of the 2002 promotion, she took a Romano-Algerian doctoral scholarship, and finished her $\mathrm{PhD}$ thesis in automatic control form Politehnica University of Bucharest, Romania in 2008

She worked as an assistant professor at the Ziane Achour University of Djelfa, Algeria from November 2008 to December 2010. Presently, she is an associate professor at the Ziane Achour University of Djelfa, Algeria. Dr. Azzouzi has publications in many journals and she participated in many international conferences. She served as the reviewer and editor of known journals and she joined as an organizing/scientific/international program committees member of many international conferences. Recently, she was elected as the IEEE Algeria Subsection secretary. 
Optical and Combustion Energy 
